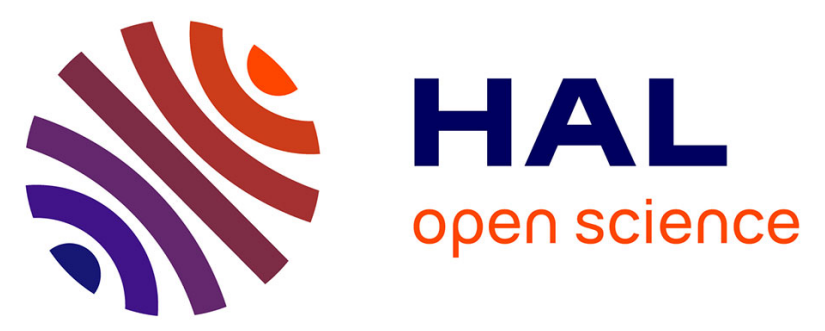

\title{
SUSTAINABLE DEVELOPMENT AND THE PROCESS OF JUSTIFYING CHOICES IN A CONTROVERSIAL UNIVERSE
}

Olivier Godard

\section{- To cite this version:}

Olivier Godard. SUSTAINABLE DEVELOPMENT AND THE PROCESS OF JUSTIFYING CHOICES IN A CONTROVERSIAL UNIVERSE. Sustainable Development: Concepts, Rationalities and Strategies, Dordrecht, Kluwer Academic Publishers, 'Economy \& Environment Series', pp.299317, 1998. hal-00622855

\section{HAL Id: hal-00622855 \\ https://hal.science/hal-00622855}

Submitted on 29 Nov 2011

HAL is a multi-disciplinary open access archive for the deposit and dissemination of scientific research documents, whether they are published or not. The documents may come from teaching and research institutions in France or abroad, or from public or private research centers.
L'archive ouverte pluridisciplinaire HAL, est destinée au dépôt et à la diffusion de documents scientifiques de niveau recherche, publiés ou non, émanant des établissements d'enseignement et de recherche français ou étrangers, des laboratoires publics ou privés. 
in Sylvie Faucheux, Martin O'Connor and Jan van der Straaten (eds), Sustainable Development: Concepts, Rationalities and Strategies, Dordrecht, Kluwer Academic Publishers, 'Economy \& Environment Series', 1998, pp 299-317.

\title{
SUSTAINABLE DEVELOPMENT AND THE PROCESS OF JUSTIFYING CHOICES IN A CONTROVERSIAL UNIVERSE
}

\author{
Olivier GODARD \\ Centre International de Recherche sur l'Environnement et le \\ Développement (CIRED) - - URA 940, CNRS \\ Ecole des Hautes Etudes en Sciences Sociales
}

\begin{abstract}
"Sustainability is not regarded seriously by those who really count, namely those at the top of political structures and those who control the flows of national and international capital. (...) One can only be cautious about an effective future role for the concept of sustainability. It is probably going to languish as a 'good idea' which cannot be put into practice -- like 'democracy' and 'accountability'." (O'Riordan 1988)
\end{abstract}

\section{The Social Project of Sustainability, a Cloak for Various Absences}

This paper focuses on the study of sustainability as a candidate principle of legitimacy. Its purpose is firstly to highlight the potential of this principle and then to identify sources of the disenchantment that has contributed to its current ambiguous and controversial status.

The primary task of language is to name what is not self-evident and to bring absent beings onto the social stage. By this, a symbolic world is formed to transcend the immediacy of conspicuous presences and absences, and thus provide the means for interpretation. Under the appearance of positive and unquestionable comprehensiveness exuded by the notion of sustainability lie a set of profoundly unsettling lacks and absences. These lacks and absences are felt on a number of levels:

- Many people worldwide believe that the physical and social transformation processes under way, partially represented as a development process, are incompatible with the perpetuation of the world familiar to them and to which they are extremely attached. This incompatibility even holds true for what was hitherto considered to be the most secure and, on the level of a human life, the 
most stable of elements such as the climate. They also believe that these changes are becoming unbearable for a large and growing number of human beings plunged not only into material misery, but also into social exclusion and cultural destruction. The fear is (often unvoiced): will there even be a future world for humanity? Will humanity find a way to be fit for inhabitation?

- Beings who are absent from the social, economic and political stages on which development paths are chosen in the shadows of a half-consciousness swayed by minor and major decisions are newly acknowledged with legitimate interests and values: groups being the victims of social exclusion, who have neither the power nor the means to make themselves heard; future generations of humans still in limbo to whom some parties propose giving rights before they are born into the world; possibly, according to others, non-human living beings whose life courses unfurl on the same planet as us, and even those collective beings forming ecosystems, biomes and the biosphere. The question raised here concerns the principle and methods used to represent the interests and values attached to these absent subjects for their own sake, becoming by necessity "reference" subjects rather than "preference" subjects as they are not players in the public space formed "here and now".

- Social actors still hesitate over, and have trouble agreeing on, the collective conduct to be adopted to sort out their relationships with the biophysical world that forms their environment. This hesitation and diffidence concerns firstly the very definition of situations and "common worlds", on which action relies to be pertinent. Yet it also concerns the basic principles to which stakeholders could and should refer in order to solve their differences of opinion, and criteria deemed legitimate to which they would agree to defer in order to define fair action in accordance with such principles. Over and above their inefficiency, public environmental policies have always suffered and still suffer a legitimacy problem (Godard, 1989, 1990). ${ }^{1}$ The reference to the aim of sustainability is an attempt to dispel this problem, but the fact that the lack is named does not mean that it made good. Hence the fourth level described below.

- There may be a lack of consistency and legitimacy in the doctrine of sustainable development when it is raised from the status of a simple "good idea" to a general principle of judgement for determining what is just and appropriate. This shortcoming can be associated with various reasons relating to both the field of

1 This legitimacy problem should be understood as simultaneously referring to the hesitation over the justification universes to which the problems in question should be referred and the lack of appropriate representation of these problems in each of these universes. This characterisation can be likened to what Brian Wynne (1992) called "indeterminacy", as opposed to the uncertainty that could be reduced by a greater research effort to track down the statistical relationships. This indeterminacy concerns the basic agreements relating to operations of description and classification, which enable equivalence relations to be found between situations and between objects. 
principles and the institutional and practical facilities likely to be used to implement these principles:

-- The conceptual uncertainties and the vagueness of the terms used in the doctrine of sustainability;

-- The incompatibility manifest in some theoretical views of sustainability compared with the axiomatic framework common to the different principles of legitimacy operating today in Western democratic societies -- that is, the founding precepts of the "city" model ${ }^{2}$ as described by Boltanski and Thévenot (1991) summarised in Figure 1;

-- The lack of support from objects and causal relations, even though they are needed to make the justification tests stand up, in these controversial universes ${ }^{3}$ currently underlying the main problems affecting the global environment;

-- The shortage of sufficiently well-defined indicators, procedures and tests for sustainability, adequate to resolve disagreements.

For all these reasons, the initial shortcoming to which the invention of the notion of sustainability was intended to be a response is aggtavated by a more serious deficiency, as the new barely brandished principle crumbles or as fear develops over the new monsters to which it could ultimately give birth. ${ }^{4}$ This risk is rising because lassitude mixed with the desire to plaster over the cracks can lead our contemporaries, without any real conviction, to leave the field open to actions taken by bureaucracies in search of new ways to assert their power and authority, to the ideological terrorism of small prophetic groups, and to the strategic manoeuvres of major industrial and business organisations now inclined to present themselves as the new guardians of collective legitimacy.

2 This model presents in a synthetic way the main principles of legitimacy at work in contemporary Western society. We make use of it here without going into the details of its origins and specification.

3 These controversial universes, as opposed to stable universes, are defined by the following properties (Godard, 1992, 1993): the primacy of the scientific and social construction of problems over the direct perception by the people; the weight of scientific controversies and uncertainties affecting aspects of essential phenomena from the point of view of action; the importance taken by the distinct representation of the interests of third parties absent from the decision-making stage of "here and now"; the presumption of irreversibility affecting phenomena deemed non-subordinate and therefore preventing the expectation of the stabilisation of the state of knowledge from becoming an indisputable strategy.

$4 \quad$ In France, this concern about the new social and political monsters that the notion of sustainability, seen as the "new ecological order", could generate is well illustrated by the media success of Luc Ferry's theses (1992) in the run up to the 1993 general election and the often passionate rejection of Hans Jonas' proposals (1990), even though both reactions were based on misinterpretations and oversimplifications (see Hourcade, 1993; and Ricoeur, 1993). 


\section{The Need for Public Justification}

The search for agreement on collective actions and rules intended to manage individual conduct and conflicts over the respective positions of members in a society is subject to a general requirement of public justification. Debates, tests and judgements involved draw on some basic agreements and conventions, which we will call "common superior principles" following Boltanski and Thévenot (1991). It is at the end of such justification work that actions undertaken or new norms and classifications adopted will be seen as legitimate. Examples of this type of process can be found in court cases, motor races and economic calculations of the profitability of an investment. They are all tests, even though they correspond to different situations, intended to determine the appropriate action or order. The requirement is twofold: to find a suitable response to the specific circumstances of the situation requiring a judgement, but also to link the situation to a more general representation of an ideal order supposed to sustain a common good shared by all the members of the society.

Understanding the concept of legitimacy in this way, it can be said that the idea of sustainable development is presented and used today by many groups, organisations and institutions as a new standard for justifying actions taken in the many areas of technological and economic development, demographic growth, town and country planning, natural resource use and exploitation, and biophysical environmental protection, to name but some of the fields identified using their most common names.

\section{Sustainability as a Rhetorical Resource for Criticism}

However, far from being firmly established for its positive content, the sustainable development requirement is first and foremost used to back up arguments criticising current situations and practices: for example, your industrial, demographic, agricultural (and so on) development is not sustainable! Now, this sort of statement is not just an objectively scientific observation, but rather is an objection, a criticism and a demand for explanations: "By not being sustainable, your development is harming others" -- that is, all those others whom the speaker is claiming to represent. And the spokesperson continues with, "You are overstepping your rights, you are not respecting your obligations, you should make amends or at least take steps to put a stop to this intolerable situation."

There is no lack of examples of such denunciations. The history of the emergence of this notion is littered with them. Moreover, they come from all directions. Accusers and accused swap roles as if in a game of table tennis where the ball changes according to the direction of play. For example, in relation to the climatic risk associated with the increase in anthropogenic greenhouse gas emissions, consider the argument put forward by a London-based non-governmental organisation called the Global Commons Institute (GCI). This NGO had an institutional and media success in March 1993 when it 
presented a shocking figure establishing the extreme illegitimacy of the development styles of industrialised countries and the underlying international economic order. ${ }^{5}$ It was estimated that the poor Southern countries pay the industrialised countries an annual energy consumption subsidy of 3.4 trillion dollars. In return, the Northern countries, in the form of the Global Environmental Facility (GEF), conditionally offer a sum equal to a mere $0.00006 \%$ of their "debt" to the South! This revelation is supposed to be based on the idea of sustainability, interpreted as a normative and even legal principle as it leads to concepts of debt and obligation. The hypothesis is as follows. According to the first report from the Intergovernmental Panel on Climate Change (IPCC) (Houghton et al., 1990), global emissions need to be reduced by $60 \%$ in order to stabilise the atmospheric concentration of $\mathrm{CO}_{2}$ at 1990 levels. This would leave a residual level of emissions compatible with this stabilisation of 2.4 GTC or 0.46 tonnes of carbon per planetary inhabitant per year based on 1990 world population figures. The authors take this value to be a universal sustainability norm and use it to determine, on the basis of real emissions, the countries "in credit" (emitting less than the norm) and the countries "in debit" (emitting more than the norm). They then put a value on these quantities using the average value of the macroeconomic coefficient for the energetic efficiency of fossil fuel (GNP per tonne of carbon ratio). From this, they arrive at an evaluation of the "debt" taken out each year by the Northern "debtor" countries with the Southern "creditor" countries.

This example shows how turning the idea of sustainability into a legitimacy norm depends on a group of operations which, in this case, have only been partially carried out and even then only in the form of legal fiction: ${ }^{2}$ the scientific definition of a function of climatic and biospheric response to various levels of greenhouse-effect emissions; the socio-economic evaluation of the consequences of induced changes and the assessment of sustainability thresholds, or rather unsustainability; an international authority's appropriation of the rights to the atmosphere previously available to all; the international distribution, based on a rule deemed fair, of rights compatible with the chosen sustainability norm; and the definition of transitional mechanisms, incentives and penalties to ensure compliance with the new rights.

If sustainability is to become an acknowledged principle of legitimacy and be accorded the means it needs, all of these stages should pass through the filter of

\footnotetext{
5 This militant organisation managed to gain entry to the international institutional climate talks and take part in the International Negotiations Committee meeting on the climate agreement held in New York in March 1993. The figures that it presented at this meeting were presented by the United Nations Inter Press Service Daily Journal (Dayal, 1993) as coming from an "environmental research body".

6 Today's world of sustainability is riddled with legal fiction. Examples of this are the equal right of each global citizen to the atmosphere, historical responsibility, and the "natural debt" accumulated by the countries that have taken more than their fair share of the common patrimony formed by the atmosphere and the earth's natural resources. To see how such fiction may become systematised, see for example Agarwal and Narain (1992).
} 
justification, notably regarding the invention of appropriate tests to resolve disagreements and arbitrate contradictory claims. The logic of denunciation, as employed by the GCI, relies on the affirmation of a set of definitions and principles presented as self-evident and woven into a coherent whole in order to produce an effect of revelation about the "real nature" of a situation. Clearly, a form of constitution of the reality and a "superior common principle" need to be presumed within this architecture. This is epitomised by the formula, presented as axiomatic by the GCI, which posits that "survival and equity are now inextricably linked."

\section{The Semantics and Axiomatic of Sustainability as a Principle of Legitimacy}

Denunciation operations can only have an impact on the targeted situations or parties if the elements used to back up the arguments are themselves consistent enough to impress. A group of concepts marks out the territory of the new principle by introducing a whole host of topics: ecological equilibria, sustainability considered here in a more technical sense, the common patrimonial earth, equity for future generations, the finite and fragile world, survival, responsibility, irreversibility, complexity, and the precautionary principle. These concepts slot together to form a founding myth from which all argument emanates. This myth is as following: the present end-of-century generations have become a "geological force" under the combined effect of technological and demographic growth. They are discovering that the planet is a finite, fragile world and that they are exhausting its resources and threatening its ecological equilibria, thereby provoking scarcity whose reign will extend to all the generations to come. This new power acquired by man gives him a new responsibility towards future generations: the earth and its resources belong to all generations and, as such, are humanity's common patrimony to be preserved and managed for the good of all. The very survival of the human race, the supreme common good, is at stake. In spite of the complexity of our world, which still prevents science from always providing for certitude, the irreversibility of the major developments affecting the planet demands immediate action in line with a precautionary principle. This principle dictates the adoption of safety measures in the name of the superior ecological interest of humanity whenever there is a doubt.

This myth is sufficiently consistent to make sustainability a serious candidate as a justification principle for development choices. This is illustrated by the fact that the main organisations involved in this field feel obliged to produce declarations, programmes and doctrines on "sustainable development". We are not just talking about the UN organisations, but also about such bodies as the World Bank (1992) (in their Report on World Development), the European Community (CEC 1992), and the International Chamber of Commerce (1991). 
Figure 1. The Axiomatic Base for Legitimate Orders of Justification: The "City" Model following L. Boltanski and L. Thévenot (1991)

\section{A1. The Principle of Common Humanity}

- What members of the "City" have in common: mutual recognition and symmetric relationship

- Distinction established between human persons and non-human beings

- Only human persons are the members of the "City"

\section{A2. The Principle of Dissimilarity}

- There are several possible social positions for members

\section{A3. The Principle of Common Dignity}

- Each member has an equal formal potential of access to the various social positions

\section{A4. The Principle of Greatness Ordering}

Differences in social positions are turned into an ordering of greatness

A5. The Principle of Sacrifice (or Investment Formula)

- Access to "Greatness" (upper social positions) has a cost, implies a sacrifice

\section{A6. The Principle of Superior Common Good}

- Having the position of a Great member provides a common good for all members, and not only a personal satisfaction (happiness, power, reputation...) 
Here can be seen a number of the attributes essential to a principle of legitimacy in modern societies. First, the aim is to be able to rank projects, actions, countries, companies, behaviour and situations in terms of their sustainability. Corresponding to this ordering, assuming a set of different states, is a hierarchy of social value going from the least sustainable to the most sustainable. The actors and projects at the top of the sustainability ordering produce a common superior good, shared by all humanity through all its generations, including the less significant parties in the sustainability order. These "leaders" also give the others a much-needed benchmark and example to be followed by those of lower ranking within the present generation. In addition, they ensure the dignity of the present generation with regard to generations to come. Lastly, the content of the debates on the economic costs of policies claiming to be in keeping with the order of sustainability considerations shows that moving up in this hierarchy involves a sacrifice in the form of forsaking a consumption of material goods, restrictions imposed on technological developments and a withdrawal from anthropocentric utilitarianism in relations with nature.

In this formulation, four of the axioms making up the "city" model as described by Boltanski and Thévenot (1991, pp. 96-102), laid out in Figure 1 below, are thus potentially satisfied: the principle of difference (A2), the principle of Greatness ordering (A4), the investment and sacrifice formula (A5), and the principle of the common good resulting from the activity of the Great (A6).

At the same time, the principle of sustainability establishes a new shared world -that is, a new reference reality, operating in novel time-space continua as regards principles of legitimacy. The biosphere and the planet Earth with their exchanges and circulations, their regulations and interlocking hierarchies, produce a dense and diversified space distinct in content and dimension compared with the usual concepts of space taken into account in other legitimacy universes (such as civic space, broken down into national territories, and market space, a homogenous ground for the circulation of merchandise free from domestic and political obstacles). Long-term time horizon is, for the first time ever, interwoven with action time and drawing closer to the time fonstants used by the universal sciences (ecological developments, geomorphology, etc.).

On the operational level, the sustainability myth offers an extremely wide-ranging scope, from which we extract three aspects for comment:

- We generally expect a legitimacy test to link the local (the situation provoking the disagreement) to a well-formed general shaping relating to a superior principle, expressed in the codification of rules and the standardisation of the objects to be used to carry out the tests. The aim of the sustainability principle is, indeed,

\footnotetext{
$7 \quad$ For example, the implementation of the "historical responsibility" concept results in proposals for rules governing the distribution of atmospheric rights to be organised "here and now", which include greenhouse-gas emissions since the pre-industrial period: see Agarwal and Narain (1992).
} 
precisely to provide a way of judging local realities and processes in the light of their more general significance at upper levels reaching as far up as the entire biosphere. A catch of fish is interpreted with regard to the survival of the species. A soil irrigation technique is evaluated using the yardstick of global trends in cultivable surface areas, productivity and the demographic boom. A change affecting space, such as deforestation, is considered from the point of view of its contribution to greenhouse gas emissions or the balance of biodiversity. This ability to give meaning to local phenomena by linking them to a general consideration is undeniably an essential attribute of any principle of legitimacy.

- The situations that the principle sets out to cover include both scientifically stabilised universes, in which causal relations and the representation of potential damage are deemed sufficiently well-formed, and the scientifically controversial universes where this is not the case. The precautionary principle is supposed to provide an adequate judgement criterion for this second type of situation (Cameron and Wade-Gery, 1995).

- The consideration of a humanity with an indefinite number of generations, with its implications in terms of responsibility towards the future and the common patrimony to be passed on, provides the grounds for the obligation imposed on the "rich" to transfer to their most underprivileged contemporaries the means needed to enable them to assume their sustainability responsibilities towards future generations and, in so doing, to acquire the minimum dignity required to be a member of a humanity ordered according to the norm of sustainability. In other words, in the sustainability order, the principle of intergenerational equity establishes a princifle of intragenerational equity instead of conflicting with it as is thought by some. ${ }^{8}$

So is all this for the better? Can we conclude that sustainability is already a wellformed principle of legitimacy? We do not believe so. Admittedly, the mark of the "city" model's "common humanity" axiom (A1) can be seen in the last argument given, showing how the intergenerational equity requirement includes the need for a form of intragenerational equity. Yet it is precisely over the respect of this axiom (A1), and also

$8 \quad$ In her study of the principle of intergenerational justice, Edith Brown-Weiss (1989, pp. 44-45) has observed: "the principle of the conservation of access implies that all people should have minimal access to the common patrimony. (...) insofar as some of them are too poor to have effective access, the others should help them to gain this access. (...) we cannot successfully conserve the natural and cultural resources for our descendants without conserving the environment in which they live. Consequently, we should help the underprivileged strata of our community to enable them to fulfil their conservation obligations." Robert Solow $(1992,1993)$ has questioned this presumption by posing a paradox of distributive equity: if the crux of sustainability is a concern for the fate of far-off future generations, surely this welfare concern should be turned even more to the advantage of those in the depths of misery today. Yet this concern will be reflected by more consumption and less investment which, in Solow's concept of sustainability centred on the maintenance of capital, means that sustainability itself comes into question. 
the axiom requiring "equal power of access to different states" (A3), that the norm of sustainability stumbles as a general principle of legitimacy. Also in question is the present ability of this principle to produce practical tests capable of ordering the situations and putting an end to disagreements and denunciations.

\section{Weaknesses and Inconsistencies in the Principle of Sustainability}

Mainstream economists, in particular, have gleefully set about dismantling the notion of sustainability and exposing its lack of precision, its inconsistencies and its distinct inferiority relative to the concepts emanating from the classical theory of optimal growth (for example, Nordhaus, 1992). More generally, most of the analysts writing about the subject of sustainability start their papers by underscoring the vagueness surrounding the notion and the large number of conflicting definitions and concepts. Michael Marien (1992, p.732) epitomises a widespread feeling in the introduction to his review of the English literature on the subject. He considers "that there are too many authors presenting competing, complementary and sometimes contradictory messages about what the problems are and what should be done to construct a viable future." This statement hints, to say the least, at the fact that as a principle of legitimacy, the sustainability concept is not yet ready to take on the role expected from it. Discussion on this matter could cover wide territories; we will limit our remarks to a few theoretical points.

Two divergent perspectives, generally called anthropocentric and biocentric, coexist in the literature on sustainability. The biocentric view has been contemplated by many. Callicot (1992), for example, puts forward a case for taking into account an intrinsic value of living beings in the name of a new scientific understanding of the incorporation of the human species in the biosphere. Other experts take stands as a result of concern about the strict application of a functionalist or narrowly economic anthropocentric concept (e.g., Kuik and Verbruggen, 1991). Yet in all cases, the biocentric view comes up against a major problem in that it violates the axiom (A1) of common humanity, which defines the reference community as a community of people who mutually acknowledge each other as humans and fellow men. This difficulty is stressed by Paul Ricoeur (1993, p.15) when he states that he believes the notions of rights and duty cannot be extended beyond the human sphere. Each time a hypothesis makes ecological sustainability an end in itself and an organisational principle for action and management, it is rendered invalid from the point of view of the "city" model.

The anthropocentric view obviously does not have this particular problem, but does suffer from two other important problems. To be suited to the stakes of sustainability, a principle of legitimacy has to be able to provide a coherent and satisfactory representation of the future. The "city" model imposes a synchronic order on the people and social states by focusing on the conditions for reaching an agreement between the people making up society and having to determine the conditions of their 
co-operation and the distribution of social goods. This is why the axiom of common humanity (A1), which establishes a basic difference between the humans faced with the problem of a mutual agreement and the other beings, also posits a fundamental equivalence and symmetry between all the members of the human community considered. Yet time does introduce a gap between remote generations. This split has two features:

- These generations are not both represented in the same community and cannot contact each other in order to agree on a common good;

- They are in an extremely lop-sided relationship, as the former generations create the later generations and give them (impose on them?), in that same motion, their identity and the world in which they are going to have to live their life.

It is ultimately from the decision of the former generations that the later generations come into existence or not.

This line of argument is also taken up by those who consider that under no circumstances can the present generations wrong future generations. To each behavioural regime, however little it may modify the present generations' decisions, correspond future generations who will be different in both quality and quantity. That is to say, those yet to be born will not be the same people. They will therefore not be in a position to criticise their parents for the state of the world they have left them as they would not have come into the world had their parents behaved differently. An attempt could probably be made to overcome this "problem of identity" by, for example, siding with the utilitarian point of view (Beckerman and Pasek, 1993; Birnbacher, 1994). Yet the clearest implication of this is that intergenerational justice cannot easily be addressed as a problem concerning the optimisation of a distribution of well-being. It would be more suitably viewed in terms of minimum basic rights to be guaranteed so as to ensure the human dignity of all humans in all generations, and of the desire of present generations to pass on things they consider to be the most critical for defining their own identity and being rightly acknowledged by their remote successors. It is basically the value of the responses to this problem of asymmetry that tests a principle of legitimacy's suitability to the situation to be decided on when a sustainability risk is raised.

All the hypotheses picturing the successive generations as a human community similar to that of a society of co-present people, such as extensions of Rawls' veil of ignorance to the intergenerational relationship, are unrealistic as they ignore the fundamental asymmetry introduced by the procreation relationship. This holds true in spite of the fact that, since the condemnation of eugenesis, attempts are being made to tone down the implications of this relationship as much as possible by, for example, subjecting demographics to statistical laws on which forecast approaches can be based rather than calling on a principle of responsibility. These hypotheses also err by overlooking the fact that the successive generations are incapable of having the same power of access to the different social states (axiom A3) as all the accessible states considerably change over time (the "irreversibility effect"). 
An alternative solution is proposed by analysts such as Rémi Barbier (1992), who place the representation of future generations within the community formed by the present generations. The argument is as follows. As environmental changes are the remote "carriers of existence" from present generations to future generations, symmetry can be re-established by placing the representation of the latter in the present time. Generally speaking representation techniques are now well developed, though Northern societies are often said to be affected nowadays by a crisis of the political representation. In principle, this solution has the big advantage of reinstating an initial community made up exclusively of co-present members. Yet it remains to be seen how the representation mechanism can be compatible with the common dignity axiom (A3). As a social state, the representation function must also be able to be accessible to all and must not lead to the creation of two classes within the community: those only entitled to speak for themselves and those authorised to speak for the absent third parties. Above all, it remains to be seen how this capacity to represent future generations can possibly be authenticated, as the usual validation procedures (elections, etc.) are not available in this case. What tests could be used to judge self-proclaimed and contradictory claims to represent future generations?

Lastly, the general virtue of tests is that, if accepted, they can put an end to conflicts and disagreements in a way that disallows the introduction of rhetoric. Yet in order to do this, a world of well-defined and standardised things (devices, technical objects, natural beings), on which all members of society can firmly rely, need to be constituted. However, the context of scientific controversies and incomplete understanding so characteristic of knowledge about the global environment actually reflects the inability of existing ecological objects $\left(\mathrm{CO}_{2}\right.$ emissions, the spread of chemical compounds in the sea, deforestation, etc.) to establish guaranteed equivalence with future states so as to be considered as the legitimate representatives of these future states. The social pacification expected from the world of objects is a cruel disappointment here. The same shortcoming is found in the link between local and general phenomena. Complexity is the name given to the lack of information and knowledge available to the human observer to give an account of the general sense based on partial knowledge of the local mechanisms and realities (Atlan, 1979). It therefore becomes perilous to attempt to make general sense of local phenomena in any other than a prudent and conjectural fashion, but this also opens the way to strategies of stakeholders backing contradictory interpretations. This has led us, in a different context, to underscore the "entangled hierarchy" structure underlying the concept of the environment. This concept is caught between a reduction to the self-centred logic of the human system and the all-encompassing presumed, but elusive, view of the environment as a metasystem (Godard and Salles, 1991).

In view of these problems, the question should doubtless be raised as to whether sustainability is really a new generic principle or whether it should rather be looked as an extension of existing principles of legitimacy to a new field of action and concern. In this case, the rhetoric and tests of sustainability could be reduced to classic 
tried-and-tested rhetoric and tests. Take the example of the equity characteristic of the "civic city": the fundamental equality of rights and freedoms for the citizens of the world, and the inference of a charter of rights and obligations for everyone based on exercising a general will leading to such concepts as the "equal right to the atmosphere" posited by Agarwal and Narain (1992, pp. 190-195). Everyone would agree that this type of equity is strongly present and even dominant in the sustainability doctrines put forward today and in the proposals claiming to take their inspiration from them. Does this then mean that sustainability is nothing more than an attempt to both extend the "civic" principle to all humanity, regardless of national borders and the democratic communities they encompass, and to subject to it the economic development processes typical of the contemporary period, sheltered from industrial and market principles? With such a reduction, we would definitely lose something of the heroic innovation. Yet we might gain in efficiency, as the existing principles of legitimacy come with recognised tried-and-tested credentials.

We will study this question by looking at the way in which different "cities" construct intertemporal equivalence, because it is here where the main problem lies.

\section{The Various Legitimate Ways to Ensure Equivalence with the Future}

Amongst the principles of legitimacy that have currency in modern societies, only two -the domestic city and the industrial city -- explicitly incorporate temporality into the world they create. The domestic city is organised around procreation relationships and is therefore directed by the past and steered by traditional values. The industrial city is steered by values of efficiency and progress and is organised around the capacity of machines and technology to ensure equivalence with the future via production. The other principles rely on various devices to translate temporal situations into standardised situations that fit in with their corresponding worlds. We will consider just three equivalencies here: the domestic and the industrial as already mentioned, and also the market world (in view of its incontestable political significance). ${ }^{9}$

$9 \quad$ The market world is, as we will discuss below, a world of trade and contract availability where values can readjust at any time, without memory or future. As regards other legitimacy orders, the reference point for the civic world is the formation of a general will coming from free and equal citizens and its key test is the elective process that commits the society's members "here and now"; and the inspired world admittedly evinces a reference to another era, but this other era is essentially removed from a time context and only takes on the superficial appearance of a past or future time. 


\subsection{DOMESTIC EQUIVALENCE: THE PATRIMONIAL FORM}

The "domestic city" gives rise to the notion of patrimony, which co-ordinates two functions. The first is a synchronic function of the subject's strategic adaptation, in both material and identity terms, to life's unforeseen events. The second is a diachronic transmission function through which the management of a patrimony is differentiated from the management of a capital (Godard, 1990; Godard and Salles, 1991). This construction, which recognises the tension between these two functions, only manages to stand up with the help of hypotheses about the subjects of the domestic city: they form a line, house or body, that is, an intergenerational patrimonial group, which is the true symbolic owner of the patrimony. This change of pertinent reference subjects, from individuals to intergenerational groups, ensures the unification of the two, potentially antagonistic, functions by linking them to each other. The present holder of the patrimony has to survive in order to ensure the proper management and transmission of the patrimony that he has received. He therefore has a duty to use this patrimony for his personal survival when circumstances so dictate, especially since the identity value of the patrimony relies less on the materiality of the goods making it up than on the personal transmission chain formed for them. At the same time, the survival of the patrimonial group can be ensured by the assumed transmission.

This type of construction proves to be soundest in the traditional world, where the make-up of the patrimony is void of ambiguity as the patrimony to be passed on is structured by the patrimony received. So to make the adaptive value of the bequeathed patrimony consistent, the world in question has to be predictable and slow to evolve. In a world subject to an intense process of global change, there is a growing contradiction between the two methods of patrimonial identification: the identity value associated with the legacy and the now extremely uncertain adaptive value focused on presence in the world, such as this world becomes.

The adoption of the patrimonial form to understand sustainability in the contemporary context presents another substantial problem in that the order of importance in the domestic world has to be inverted. The prevailing order is constructed according to a degree of proximity and intimacy with the "great men" of this world, so as to label the symbolic goods bearing the identity of these "great men" and the patrimonial group that they personify. Wild, non-propertied nature and the planet's global equilibria are therefore the strangest beings you could possibly find described as patrimony!

Lastly, the patrimonial form built on the procreation relationship will normally expose itself to the asymmetry initiated by this relationship, with all the destructive consequences that this can have for the principle of legitimacy. The first way of alleviating the asymmetrical effect consists of developing the reversal of roles in the transmission chain itself: the heir who has received and cannot give his inheritance back to his benefactor has a duty to give to a third party, who will thus receive from him. Yet this does not reinstate the symmetry of persons required by the axiom (A1). It merely 
reinstates the symmetry of roles, which ensures compliance with the axiom (A3) of equal power of access to social states. The second possible solution consists of realising that the intergenerational asymmetry in this case represents a common feature of a society formed by the only generations present, whose members are all placed in the same transmission logic in the name of the continuation of the patrimonial group to which they belong. Therefore, each member of this community should be recognised a basic dignity in the form of a patrimonial interest to consolidate This dignity can be used as the basis for generating links and searching for agreements. In so doing, the society is no longer directly organised as an intergenerational community, but merely as a community of living beings, which restores compliance with the axiom (A1). However, the price of this is a common submission to an external principle, which turns the members of the society into instruments and thus undermines their credentials as persons.

To sum up, the patrimonial form has the potential to make sense of the sustainability question by being organised around a transmission logic. Yet it stumbles over three problems that are not easily overcome:

- The vagueness of the description of the patrimony to be passed on as soon as the question is considered from the point of view of the value of adaptation and survival and as soon as the traditional references, turned towards the past, are no longer operative;

- The reversal of the order of importance that would be required to mobilise the patrimonial form to contain those objects, Nature, least well-suited to this status;

- The asymmetry of the procreation relationship, which can be completely overcome only by making the society's members lose their credentials as persons, following their subservience to an external principle.

\subsection{INDUSTRIAL EQUIVALENCE: SUBSTITUTABILITY THROUGH TECHNOLOGY AND PRODUCTIVE INVESTMENTS}

Robert Solow (1993) expresses a position well-established with a number of economists: that most natural resources and environmental assets have a value, which is not based on what they are, but on their services and functions. As such, they can easily be replaced by using technology and investment, i.e., capital formation. Unsustainability does not therefore generally reside in the use of non-renewable assets, but in the fact that the profit derived from this use is not reinvested. Solow acknowledges the irreplaceable

10 Here resides the principle underlying the intervention and decision-making aid approach, which has developed in France under the name of "negotiated patrimonial management". This approach endeavours to encourage the appearance of methods of co-operative management of environmental and natural resource commons (forests, water tables, rivers, etc.) of interest to a whole host of social actors. See Jean de Montgolfier and Jean-Marc Natali (1987). 
uniqueness of certain exceptional assets such as the Lincoln Memorial and the Yosemite National Park in the United States, but asserts that such assets are limited in number and cannot therefore form the crux of the debate on sustainability. The result of all this is that the sustainability norm proposed does not take the form of a general command to conserve such or such a resource, and even less a command to conserve all the natural elements in an unaltered state. Beings in the industrial world are only worth anything if they are productive and used to satisfy needs. So instead, the command is to indefinitely preserve the productive capacity of human societies, bearing in mind that the total capital of the society extends beyond its own productive facilities (factories, machines and buildings) to encompass everything that contributes to producing well-being, ergo including human capital and natural capital.

To what extent does the formula of investment in production capacities and technological research provide a sufficient basis for ensuring sustainability? This is obviously a question for debate. There are at least three angles of attack available:

- The time period pertinent to industrial activity, i.e., that over which the investment formula can credibly form equivalence (investment in a given factory with a sufficient probability of equivalence with the supply of industrial products for $n$ years to come), is a lot shorter than the long, intergenerational time addressed by sustainability. In other words, industrial equivalence skirts around the question of time asymmetry rather than really overcoming it.

- Industrial equivalence is based on the paradigm of a mastery of technological devices. This in itself implies full knowledge about the performances of the objects used in both the closed and controlled spaces of their industrial lives and in the open spaces represented by the consumer's habitat, the physical environments and the ecosystems. Yet industrial processes do contain an irreducible element of ignorance, which is revealed in the event of technical faults, accidents and sometimes technological catastrophes (Lagadec, 1981; Wynne, 1992) and can even be revealed later when scientific analyses find diffuse pollution phenomena. Beyond the industrial universe's paradigm of expertise in a closed and functional universe within a short time framework, the long-term reality is that of an uncontrolled dispersion and slow erosion of natural objects that technology cannot substitute. In fact, the very question of sustainability has been raised when industrial and technological investment has proven not being able to ensure controlled equivalence over the long term. Doubt is therefore cast on the ability of industrial tests to adjudge the sustainability of economic development.

- Technology and investment both depend on a prior concentration of substantial means which, by definition, are not equally accessible to all. They therefore provide only a partial response to the problem of sustainability, at best reserving it for a mere fraction of the human community. 


\subsection{MARKET EQUIVALENCE: THE CONTRACT BETWEEN OVERLAPPING GENERATIONS}

The market world forges no temporality and does not, therefore, enable the question of inter-temporal equivalence to be addressed directly. Nevertheless, the example of the market contract is put forward as a formula for solving the problem of the sustainability norm based on a similar set-up, in this regard, to that of the "domestic world": the relationship formed between two successive generations when they are overlapping and are therefore co-present and able to enter into a contract with each other. Karl Göran Mäler (1992) has proposed a model based on the reasoning underlying Hotelling's law of rent formation on a non-renewable resource market (the rent reflects the resource's expected price increase due to its future increased scarcity, which makes it profitable to conserve a certain level of the resource for future sale). This overlapping generations model solves the problem along the following lines. It is in the best interests of the young, in a productive phase, to preserve a stock of environmental resources used as production input in order to resell it later, when they retire and are consumers, to the new young who will take their place. They will draw an appreciable income from this on which to live when they join the class of the elders. An optimal conservation trajectory is traced from contract through contract, as long as the environmental resource is appropriated and the agents can form rational expectations as to the sales prospects available to them. Consequently, the contract between two successive generations is said to be sufficient to ensure a fair representation of the preferences of all the future generations to come.

This is an elegant solution as it entails two attractive factors. First of all, it reestablishes a situation of real symmetry between the generations in compliance with the axiom (A1), which is that of two partners to a mutually profitable contract. Secondly, it focuses attention and management on the concrete resources making up the world of the present generations, i.e. the most well-known objects, and thus avoids a function of representation of future conditional beings linked by evolutionary paths. It reaches a classical conclusion, from the point of view of theoretical concepts, by reducing the question of sustainability to a problem of imperfect information (agents' expectations cannot be rational) and incomplete markets (many environmental resources can neither be appropriated nor traded).

So, can the solution be convincing when applied to the justification processes? At the very least, it lacks well-constructed tests on which a judgement can be based. As with a house of cards, all the contracts are built on the last one, the contract which is to be concluded at the end of history. This event can but be conjectural, and encumbered by all the limits encountered by existing beings (persons and objects) as regards forming equivalence with future beings. For example, to what extent are the preferences of future generations similar or different to ours? To what extent might the technological universe and biophysical environment in which they will live be deduced from those of the present generations? 


\section{Conclusion}

All in all, neither the path of the generic principle nor that of the reduction to existing principles would appear to be fully satisfactory as the basis for establishing the legitimacy of sustainable development or as a way of making sustainability a principle of legitimacy by its own. We should probably resign ourselves to seeing in this idea a composite construction, still striving towards the formation of a new "superior common principle", without this principle yet being able to be completely clarified and validated.

What we have here is an example of the sort of "compromise" described by Boltanski and Thévenot (1991, p.338): "In the compromise, the participants abandon the idea of clarifying the principle of their agreement but endeavour to maintain a frame of mind aiming at the common good." If we want to consolidate the compromise developing around sustainability, it would be well advised to seek the support of tests using well-formed objects. To this end, steps should be taken to move the emphasis away from long-term and unknowable sustainability requirements and closer to secondbest criteria focused on the transitional developments and possible risks of intentional human action, the ways of managing the linking of the different temporalities in play -as regards the biophysical phenomena, their understanding and the main worlds of legitimacy (Godard, 1992) -- and the introduction of deliberation within the present generations as to what they feel best describes their identity, those things they would like to pass on.

\section{References}

Agarwal, A. and Narain, S (1992) Towards a Green World: Should Global Environmental Management Be Build on Legal Conventions or Human Rights?, Centre for Science and Environment, New Delhi.

Atlan, H. (1979) Entre le cristal et la fumée: Essai sur l'organisation du vivant, Seuil, Paris.

Barbier, R. (1992) Cité de l'écologie: Ecologie et environnement dans les conflits de justice, Centre de Sociologie de l'Innovation, Paris, September.

Beckerman, W. and Pasek, J. (1993) Environmental Policy: The Economics-Philosophy Relationship, Annual Conference of the Society for the Advancement of SocioEconomics, New York, March.

Birnbacher, D. (1994) La responsabilité envers les générations futures, PUF, (Coll. "Philosophie morale"), Paris.

Boltanski, L. and Thévenot, L. (1991) De la justification: Les économies de la grandeur, Gallimard, (Coll. "NRF essais"), Paris.

Brown-Weiss, E. (1989) In Fairness to Future Generations: International Law, Common Patrimony, and Intergenerational Equity, The United Nations University and Dobbs Ferry, New York; and Transnational Publications, Tokyo.

Callicot, J.B. (1993) La nature est morte, vive la nature!, Ecologie Politique : Sciences, Culture, Société, 7, 73-90. 
Cameron, J. and Wade-Gery, W. (1995) Addressing Uncertainty: Law, Policy and the Development of the Precautionary Principle, in B. Dente (Ed.) Environmental Policy in Search of New Instruments, Kluwer Academic Publ., (Coll. "Environment, science and society"), Dordrecht \& London, 95-142.

CEC (Commission of the European Communities) (1992) Vers un développement soutenable, COM(92)23 Final - Vol. II, Brussels, 30 March 1992.

Dayal, J. (1993) South Subsidies North's Energy Use at \$3.4 Trillion Annually, Inter Press Service Daily Journal, 1, (15), New York, United Nations, Friday, 19 March.

Ferry, L. (1992) Le nouvel ordre écologique: l'arbre, l'animal et l'homme, Grasset, Paris.

Global Commons Institute (1993) Climate Change and the Precautionary Principle, GCI, London, March 1993.

Godard, O. (1989) Jeux de nature: quand le débat sur l'efficacité des politiques publiques contient la question de leur légitimité, in N. Mathieu \& M. Jollivet (eds) Du rural à l'environnement - La question de la nature aujourd'hui, ARF Editions \& Ed. L'Harmattan, Paris, 303-342

Godard, O. (1990) Environnement, modes de coordination et systèmes de légitimité: analyse de la catégorie de patrimoine naturel, Revue économique, 41, (2), March, 215-241.

Godard, O. (1992) Social decision-making in the context of scientific controversies - The interplay of environmental issues, technological conventions and economic stakes, Global Environmental Change. Human and Policy Dimensions, 2, (3), September, 239249

Godard, O. (1993) Stratégies industrielles et conventions d'environnement: de l'univers stabilisé aux univers controversés, INSEE-Méthodes, "Environnement et économie", (39-40), December, 145-174.

Godard, O. and Salles, J.-M. (1991) Entre nature et société. Les jeux de l'irréversibilité dans la construction économique et sociale du champ de l'environnement, in R. Boyer, B. Chavance \& O. Godard (eds) Les figures de l'irréversibilité en économie, Ed. de l'EHESS, Paris, 233-272.

Houghton, J.T., Jenkins, G.J. \& Ephraums, J.J. (eds) (1990) Climate Change: The IPCC Scientific Assessment, Cambridge University Press, Cambridge.

Hourcade, J.-C. (1993) Les sciences entre philosophie et mass media ou l'incertaine légitimité, Natures-Sciences-Sociétés, 1, (4), October, 316-321.

International Chamber of Commerce (1991) La Charte des entreprises pour le développement durable. Paris: ICC, April.

Jonas, H. (1990) Le principe responsabilité, Ed. du Cerf, Paris.

Kuik, O. and Verbruggen, H. (Eds) (1991) In Search of Indicators of Sustainable Development, Kluwer Academic Publ., Dordrecht \& London.

Lagadec, P. (1982) Major Technological Risk. An Assessment of Industrial Disasters, Pergamon Press, Oxford.

Mäler, K.-G. (1992) Economic Growth and the Environment, International Economic Association Conference on Economic Growth and the Structure of Long Term Development, Varenna, October 1-3.

Marien, M. (1992) Environmental Problems and Sustainable Futures. Major Literature From WCED to UNCED, Futures, 24, (8), October, 731-755.

Montgolfier, J. de and Natali, J.-M. (1987) Le patrimoine du futur. Approches pour une gestion patrimoniale des ressources naturelles. Ed. Economica, Paris. 
Nordhaus, W.D. (1992) Reflections on the Concept of Sustainable Economic Growth, International Economic Association Conference on Economic Growth and the Structure of Long Term Development, Varenna, October 1-3.

O'Riordan, T. (1988) Chapter 2. The Politics of Sustainability, in R.K. Turner (ed.) Sustainable Environmental Management. Principles and Practice, Belhaven Press, London, 29-50.

Ricoeur, P. (1993) L'éthique, le politique, l'écologie. Entretien, Ecologie Politique. Sciences, Culture, Société, (7), Summer, 5-17.

Solow, R. (1992) Sustainability: our Debt to the Future, USA Today, September, 40-42.

Solow, R. (1993) An Almost Practical Step Toward Sustainability, Resources Policy, 19, (3), September, 162-172.

World Bank (1992) Development and Environment. 1992 Report on World Development. World Bank, Washington D.C.

Wynne, B. (1992) Uncertainty and environmental learning. Reconceiving Science and Policy in the Preventive Paradigm, Global Environmental Change. Human and Policy Dimensions, 2, (2), June, 111-127. 